\title{
Mechanical behavior of recycled lightweight concrete using EVA waste and CDW under moderate temperature
}

\section{Comportamento mecânico sob temperatura moderada de concreto leve reciclado produzido com resíduo de EVA e RCD}

\author{
E. Q. R. SANTIAGO \\ edielaqr@yahoo.com.br \\ P. R. L. LIMA \\ lima.prl.uefs@gmail.com \\ M. B. LEITE \\ mleite.uefs@gmail.com \\ R. D. TOLEDO FILHO ${ }^{d}$ \\ toledo@coc.ufrj.br
}

\begin{abstract}
Many benefits can be achieved by using recycled waste as raw material for construction. Some of them are the reduction of the total cost of the construction, the reduction of the consumption of energy and the decrease in the use of natural materials. The construction sector can also incorporate the waste of the other industries, like the waste of the shoes industry, the Ethylene Vinyl Acetate (EVA). EVA aggregate is obtained by cutting off the waste of EVA expanded sheets used to produce insoles and innersoles of the shoes. In this work two types of recycled aggregate were used - construction and demolition waste (CDW) and EVA. The aim of this work was to study the influence of the use of these recycled aggregates, as replacement of the natural coarse aggregate, on mechanical behavior of recycled concrete. The experimental program was developed with two w/c ratio: 0.49 and 0.82 . Four mixtures with produced with different aggregates substitution rates $(0$, $50 \% \mathrm{EVA}, 50 \% \mathrm{CDW}$ and $25 \% \mathrm{EVA}-25 \% \mathrm{CDW}$ ), by volume. Compressive tests were carried out to evaluable the influence of recycled aggregate on strength, elastic modulus and Poisson coefficient. In addition, it was evaluated the effect of the moderate temperatures (50, 70 and $100^{\circ} \mathrm{C}$ ) on stress-strain behavior of concretes studied. The results demonstrated that is possible to use the EVA waste and RCD to produces lightweight concrete. The influence of temperature was more significant only on elastic modulus of the recycled concrete with $50 \% \mathrm{EVA}$. Keywords: Ethilene Vinyl Acetate (EVA), construction and demolition waste (CDW), mechanical behavior, recycled aggregate, lightweight concrete.
\end{abstract}

\section{Resumo}

Muitos benefícios podem ser obtidos com o aproveitamento de resíduos na produção de materiais para construção, como a redução do custo dos componentes construtivos, a redução do consumo de energia e a diminuição do uso de recursos naturais. Além do aproveitamento do próprio resíduo de construção e demolição (RCD), a indústria da construção civil pode também incorporar resíduos de outras indústrias, como o resíduo de etileno acetato de vinila (EVA) da indústria calçadista. O EVAé um resíduo proveniente do excedente do processo de produção de solas de sapatos e pode ser utilizado, após moagem, como agregado para produção de concreto. Neste trabalho, concretos reciclados foram produzidos com utilização de RCD e EVA, em substituição ao agregado graúdo natural. O objetivo foi avaliar a influência do uso destes agregados reciclados sobre o comportamento mecânico do concreto sob compressão direta, em temperatura ambiente e após ser submetido a temperaturas moderadas ( 50,70 and $\left.100^{\circ} \mathrm{C}\right)$. Foram produzidas quatro misturas com diferentes teores de substituição, em volume, do agregado natural pelo reciclado (0,50\%EVA, 50\%RCD e $25 \% \mathrm{EVA}-25 \% \mathrm{RCD})$ e duas relações água-cimento $(0,49$ e 0,82). A partir dos ensaios de compressão direta foi possível avaliar a influência do agregado reciclado sobre a resistência à compressão, módulo de elasticidade e coeficiente de Poisson. O efeito da temperatura foi avaliado também sobre o comportamento tensão-deformação dos concretos. Os resultados demonstram que é possível utilizar agregados provenientes de RCD e EVA para produzir concretos leves e que a mistura com 50\%EVA apresentou, de forma mais acentuada, redução do módulo de elasticidade com o aumento da temperatura.

Palavras-chave: Etileno Acetato de Vinila (EVA), resíduo de construção e demolição (RCD), comportamento mecânico, agregado reciclado, concreto leve.

Master in Science in Civil and Environmental Engineering, Post-graduation Program in Civil and Environmental Engineering, State University of Feira de Santana, edielaqr@yahoo.com.br,Av. Transnordestina, S/N, Novo Horizonte, 44036-900, Feira de Santana, Bahia, Brazil

b Professor Doctor, Technology Department, Post-graduation Program in Civil and Environmental Engineering, State University of Feira de Santana, lima.prl.uefs@gmail.com; Av. Transnordestina, S/N, Novo Horizonte, 44036-900, Feira de Santana, Bahia, Brazil

Professor Doctor, Technology Department, Post-graduation Program in Civil and Environmental Engineering, State University of Feira de Santana, mleite.uefs@gmail.com. Av.Transnordestina, S/N, Novo Horizonte, 44036-900, Feira de Santana, Bahia, Brazil

Professor Doctor, Post-graduation Program in Civil Engineering (COPPE), Federal University of Rio de Janeiro, toledo@coc.ufrj.br. Centro de Tecnologia, Bloco B, Sala 101, llha do Fundão, 21945-970, Rio de Janeiro, Rio de Janeiro, Brazil. 


\section{Introduction}

The use of lightweight concrete permits greater design flexibility and substantial cost savings, reducing dead load, improved cyclic loading structural response, longer spans, thinner sections, smaller size structural members, less reinforcing steel, and lower foundation costs [1, 2]. However, to produce artificial lightweight aggregate is necessary high consumption of energy. These aggregates are manufactured by pyro-processing of fly ash, vermiculite or clay, at high temperature (about $1000^{\circ} \mathrm{C}$ ), to produce a material with reduced density $[3,4]$. Therefore, alternative materials have been studied to substitute these lightweight aggregate $[5,6]$.

Plastics waste, as ethylene vinyl acetate (EVA), has been used with relative success to produces concrete, lightweight concrete and components of construction [7, 8, 9]. The use of these materials as aggregate to production of concrete has economical and ecological impact due large amount of waste produced annually. During the 70 'Th decade the EVA starts to be used at the shoes industry as an alternative material to substitute the leather [10]. Currently, 17 billion pairs of shoes are produced worldwide every year, and this creates an enormous amount of post-consumer (end-of-life) shoe waste that is currently being disposed of in landfill sites around the world [11]. The cutting stage of outsole, insock and reinforcement generates about $25 \%-35 \%$ of waste that represents 80 t of waste/million pairs [12]. As ethylene vinyl acetate (EVA) represents $14 \%$, in mass, of this waste it needs large surface for placement and storage, and great costs of management due their long biodegradation period. To EVA waste, however, it is verified modifications in chemical structure at lowest temperatures. For example, at $69^{\circ} \mathrm{C}$, the surface of particles of EVA becomes smooth in with vitro respect [13]. In tropical countries, this temperature can be achieved in the interior of concrete and, due this fact, an analysis of behavior of recycled concrete under moderate temperature is necessary to evaluate if the thermal variation of EVA reduces its mechanical properties.

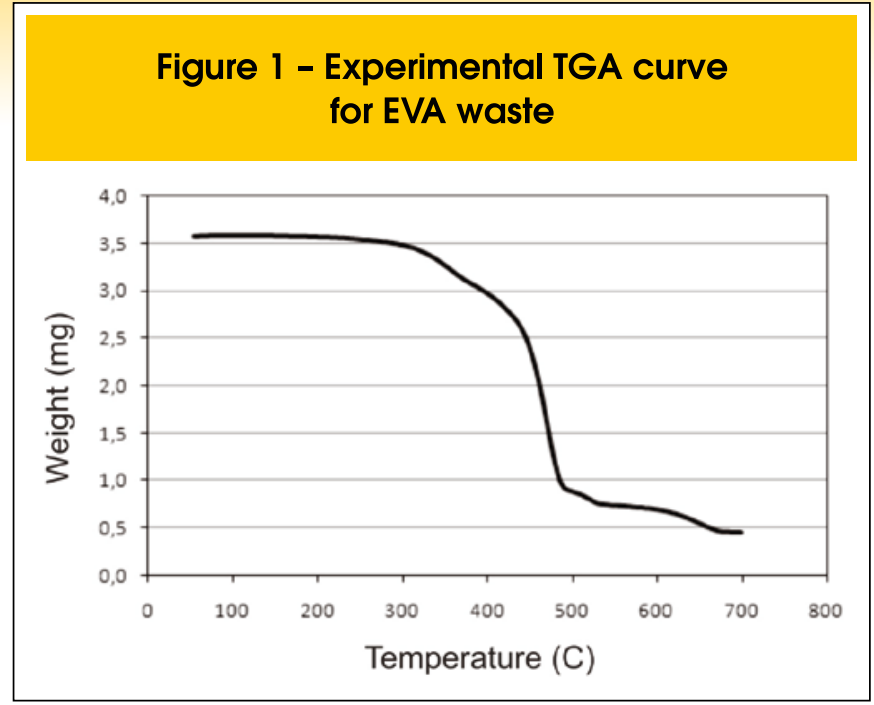

CDW constitutes a major portion of total solid waste production in the world, and most of it is used in landfill. The use of CDW as substitute of conventional aggregate has been studied for many researches $[14,15,16]$ showing good performance. Your use together with the EVA waste aggregate has as objective to minimize the loss of strength and reduction of elastic modulus of concrete, due introduction of EVA waste, without reduces the sustainability of material. The main objective of this study is to investigate the influence of recycled coarse aggregate from EVA shoes waste and CDW in substitution of natural aggregate. The effects of the type of aggregate, coarse aggregate substitution rate and water/cement ratio were evaluated on compressive strength, elastic modulus and Poisson coefficient. Additionally, effect of moderate temperatures $\left(50,70\right.$ and $\left.100^{\circ} \mathrm{C}\right)$ was evaluated on concretes compressive strength and elastic modulus, as EVA shoes waste can show structural modifications.

\section{Experimental program}

\subsection{Materials}

EVA is a micro porous copolymer achieved by the polymerization of the

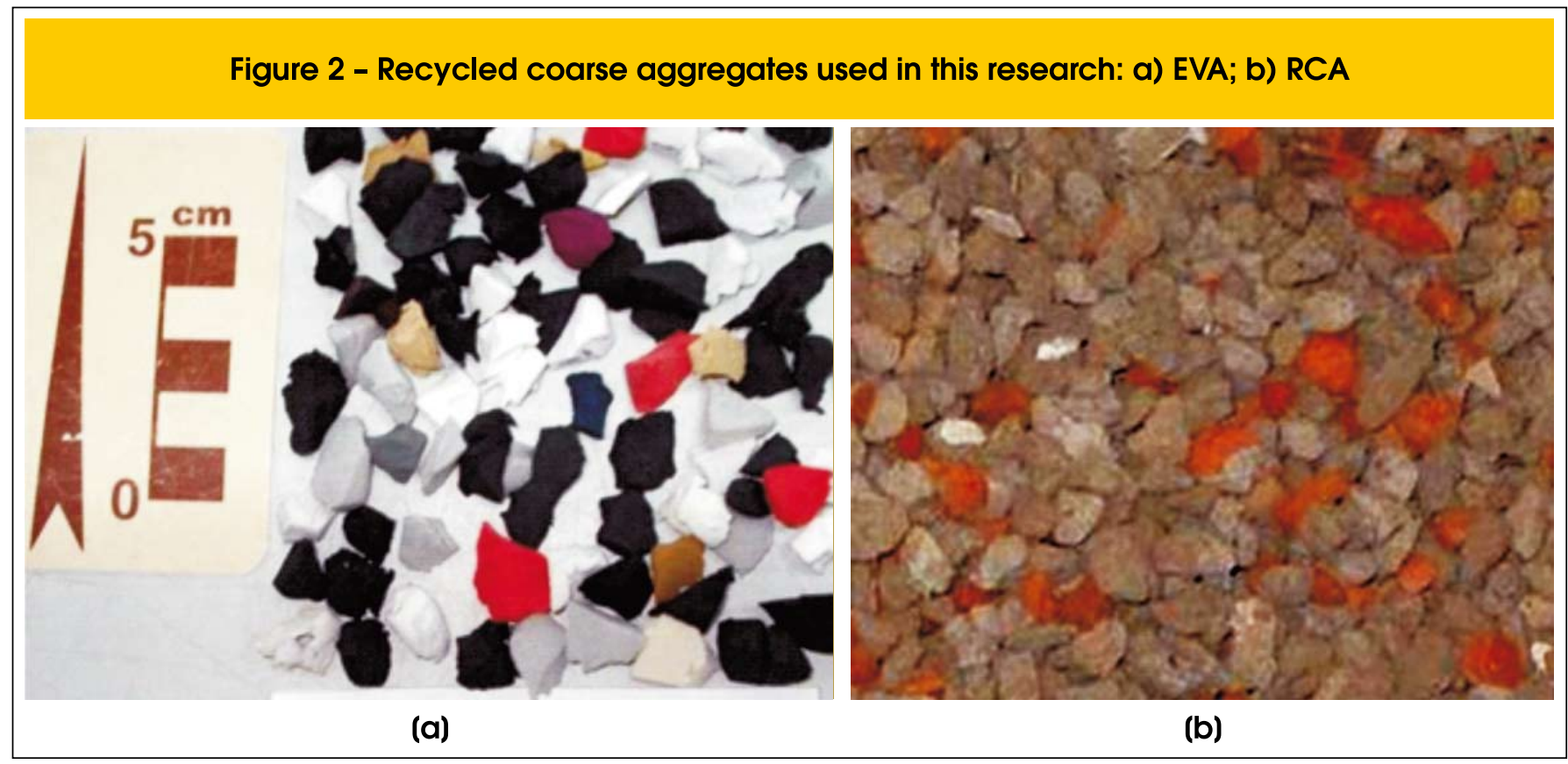




\section{Table 1 - Results of the characterization of cement}

\begin{tabular}{lccc|}
\multicolumn{1}{c}{ Properties } & Results & (NBR 5733) \\
Material finer than \# $75 \mu \mathrm{m}$ - NBR MB 3432/1991 & $0.8 \%$ & $\leq 6.0 \%$ \\
Initial set time - NBR NM 65/03 & $2: 35 \mathrm{~h}$ & $\geq 1 \mathrm{~h}$ \\
Final set time - NBR NM 65/03 & $3: 00 \mathrm{~h}$ & $\leq 10 \mathrm{~h}$ \\
Expansibility - NBR MB 3435/1991 & 1 day & $1.0 \mathrm{~mm}$ & $\geq 14.0 \mathrm{MPa}$ \\
Compressive strength & 3 days & $20.4 \mathrm{MPa}$ & $\geq 24.0 \mathrm{MPa}$ \\
NBR 7215/1996 & 7 days & $31.8 \mathrm{MPa}$ & $\geq 34.0 \mathrm{MPa}$ \\
& & $36.2 \mathrm{MPa}$ & \multicolumn{2}{c}{$3.09 \mathrm{~g} / \mathrm{cm}^{3}$} \\
Specific gravity - NBR NM 23/01 & & \multicolumn{2}{c}{}
\end{tabular}

Ethylene gas with the vinyl-acetate resin. The EVA used in shoes industry is produced with proportions of vinyl-acetate varying from 18 to $28 \%$, by weight. This composition will define the properties of material, that as a thermo fixed polymer became infusible and insoluble after industrial process [17]. The thermal analyses of the EVA indicate its phase's decomposition in the range of temperature varying between $250^{\circ} \mathrm{C}$ and $410^{\circ} \mathrm{C}$, how can be seen in the ATG curve (Figure 1). EVA coarse aggregate was achieved at Britaleve $\circledast$ Industry and is characterized by small color particles which are obtained from cutting off expanded sheets waste used to produce insoles and innersoles of the shoes. Construction demolition waste (CDW) sourced from a building demolition site at Feira de Santana City (Northeast of Brazil) was crushed into pieces using a jaw crusher and screened in $9.5 \mathrm{~mm}$ sieves to produce recycled coarse aggregate (RCA). The CDW used is basically composed by mortar $(55 \%)$, brick material $(26 \%)$ and concrete (16\%). Figure 2 shows the coarse aggregate from CDW and the commercial EVA waste coarse aggregate.

The characterization of Portland cement used (CP V ARI - ASTM Type III) is sown in Table 1. Tap water supplied by the local water supply company was used on the mixtures.

The natural fine aggregates used were $70 \%$ of one fine quartz sand (NFA1) and $30 \%$ of one medium river quartz sand (NFA2). Natural coarse aggregate (NCA) was one granitic rock.

All aggregates used were characterized according to experimental methods prescribed by NBR 7211/05 - Aggregate for concrete - specification, except for EVA waste and RCA specific gravity and RCA absorption rate. As EVA is a lightweight aggregate its particles floated into water (Figure 3a).

\section{Figure 3 - Adaptation of the specific gravity determination method to EVA aggregate: (a) NBR NM53/03 - Coarse aggregate - Determination of specific gravity and Water absorption e (b) Method Proposed by LEITE (18)}

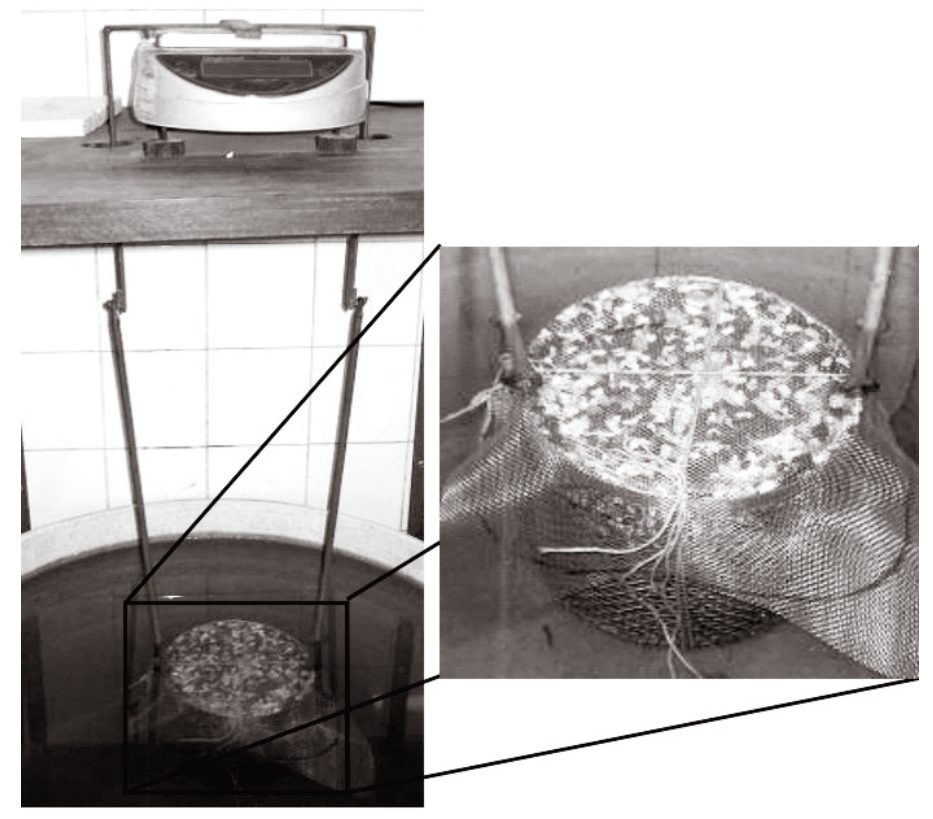

(a)

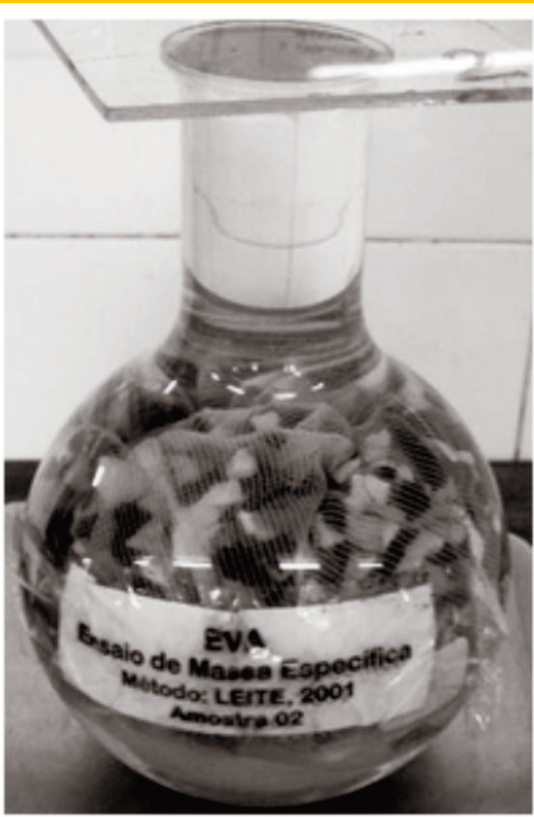

(b) 


\section{Figure 4 - Absorption rate curve $x$ log time of the recycled coarse aggregate}

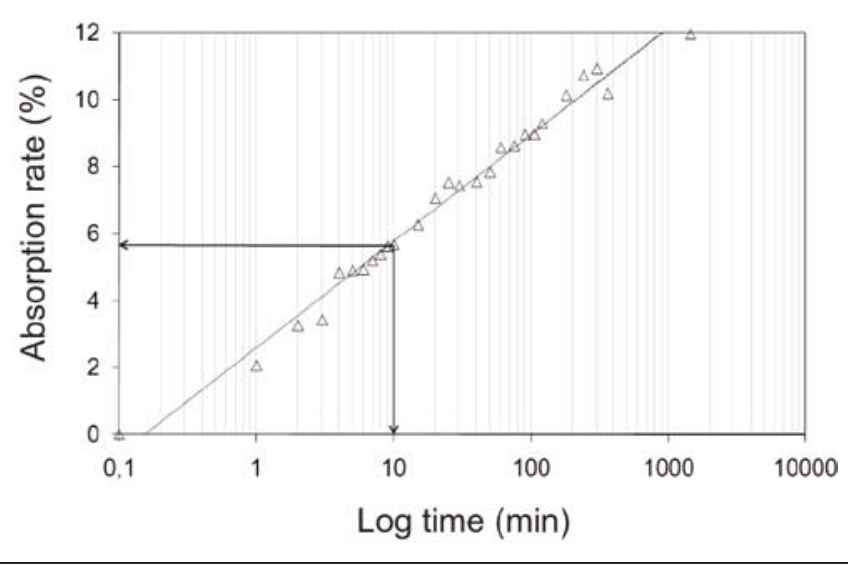

Then, the method proposed by Leite [18] was used to determine the EVA specific gravity (Figure $3 \mathrm{~b}$ ), it was also used to RCA specific gravity because the aggregate great porosity. For RCA water absorption the method proposed by Leite [18] was used to achieve absorption rate and the absorption curve to $24 \mathrm{~h}$ of material water immersion (Figure 4 ). It was observed that nearly $50 \%$ of total water is absorbed at first ten minutes. This value was used to determine the additional water in mixes of concrete, avoiding loss of workability and major modification of water/cement ratio due to the aggregate absorption rate.

All the physical properties of the aggregates, shown in Table 2, were determined at the Laboratory of Construction Materials of the State University of Feira de Santana. The granulometric distribution curves of all aggregates used are

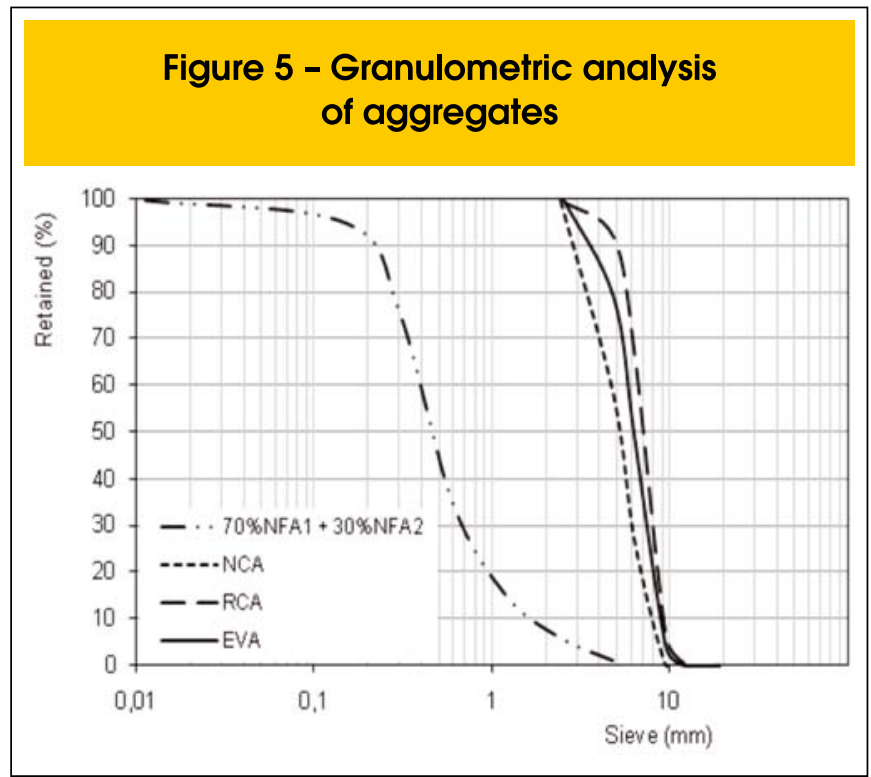

shown in Figure 5.

RCA and EVA waste aggregate show a reduction of $25 \%$ and $92 \%$ in bulk density, respectively, in comparison with natural coarse aggregate. The voids inside the aggregate particles are responsible by the reduction in bulk density, as well as, in specific gravity. This behavior requires recycled aggregate volume compensation in the pre-determined mixtures of concrete, in order to avoid higher volumes of this material.

The water absorption rate of RCA and EVA waste aggregate are, respectively, 24 and 89 times greater than natural coarse aggregate. These results imply that the absorption rate needs to be compensated to avoid that part of the mixing water would be absorbed by the recycled aggregate. To

\section{Table 2 - Results of the characterization of aggregates}

\section{Properties - (test method)}

Maximum size aggregate (mm) - (NBR NM 248/03)

Fineness - (NBR NM 248/03)

Specific gravity $\left(\mathrm{kg} / \mathrm{dm}^{3}\right)$

Bulk density $\left(\mathrm{kg} / \mathrm{dm}^{3}\right)$ - (NBR 7251/82)

Water absorption rate (\%)

Fines content (\%) - (NBR NM 46/03)

'Experimental Method: NBR NM 52/03

${ }^{2}$ Experimental Method: NBR NM 53/03

\section{NFAI NFA NCA RCA EVA}

\section{2}

$\begin{array}{ccccc}1.2 & 4.8 & 9.5 & 12.5 & 9.5 \\ 1.77 & 3.47 & 5.35 & 5.58 & 4.78 \\ 2.61^{1} & 2.57^{1} & 2.73^{2} & 2.52^{3} & 0.24^{3} \\ 1.60 & 1.46 & 1.38 & 1.03 & 0.10 \\ 0.1^{4} & 0.2^{4} & 0.5^{2} & 12.1^{5} & 44.3^{2} \\ 2.1 & 0.8 & 1.3 & 0.4 & -\end{array}$

${ }^{3}$ Experimental Method: Leite (18)

${ }^{5}$ Experimental Method: Leite (18)

${ }^{4}$ Experimental Method: NBR NM 30/03 
Table 3 - Mix proportion $\left(\mathrm{kg} / \mathrm{m}^{3}\right)$

\begin{tabular}{|c|c|c|c|c|c|c|c|c|c|c|}
\hline \multirow[t]{2}{*}{ Mixes } & \multirow[t]{2}{*}{$w / c$} & \multirow[t]{2}{*}{ Cement } & \multirow[t]{2}{*}{ NFA1 } & \multirow[t]{2}{*}{ NFA2 } & \multirow[t]{2}{*}{ NCA } & \multirow[t]{2}{*}{ RCA } & \multirow[t]{2}{*}{ EVA } & \multirow[t]{2}{*}{ water } & \multicolumn{2}{|c|}{$\begin{array}{l}\text { Additional } \\
\text { water }\end{array}$} \\
\hline & & & & & & & & & RCA & EVA \\
\hline REF & \multirow{4}{*}{0.49} & \multirow{4}{*}{424} & \multirow{4}{*}{492} & \multirow{4}{*}{212} & 992 & - & - & \multirow{4}{*}{208} & - & - \\
\hline $50 \%$ RCA & & & & & 496 & 460 & - & & 28 & - \\
\hline $50 \%$ EVA & & & & & 248 & - & 51 & & - & 23 \\
\hline $25 \%$ RCA - $25 \%$ EVA & & & & & 186 & 230 & 26 & & 14 & 11 \\
\hline REF & \multirow{4}{*}{0.82} & \multirow{4}{*}{252} & \multirow{4}{*}{601} & \multirow{4}{*}{257} & 984 & - & - & \multirow{4}{*}{207} & - & - \\
\hline $50 \%$ RCA & & & & & 592 & 456 & - & & 27 & - \\
\hline $50 \%$ EVA & & & & & 246 & - & 51 & & - & 22 \\
\hline $25 \%$ RCA - 25\% EVA & & & & & 185 & 228 & 25 & & 14 & 11 \\
\hline
\end{tabular}

EVA waste aggregate the absorption rate was completely compensated, and to RCA it was only partially compensated, according to absorption rate curve (Figure 4) and considering mixing time.

\subsection{Concrete Mix Proportions}

The concrete mixtures were produced with two different water/cement ratio, 0.49 and 0.82 , to obtain two classes of concrete with low (20 MPa) and moderate (35 MPa) compressive strength. Mix proportions for $1 \mathrm{~m}^{3}$ of four different aggregate substitution rates in concrete are presented in Table 3. All recycled concretes were produced with the same mix proportions

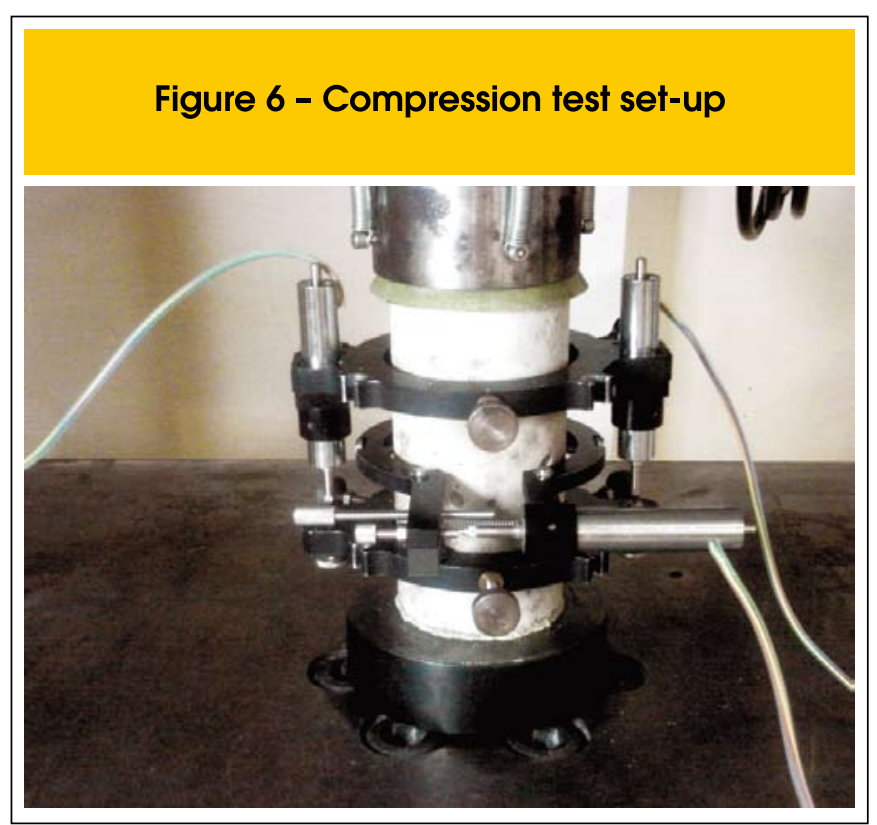

as the reference concrete, with substitution of natural aggregate by recycled aggregate by volume. Minor adjustments in weight proportions of aggregates were made to compensate for differences in density between natural and recycled aggregates, to maintain the volume of concrete produced fixed.

The recycled concrete also required a slight increase in the mixing water content (due to the different water absorption capacity of recycled aggregate) in order to achieve a good workability, measured by slump test (NBR NM 67, ABNT 1998). This reduction is a consequence of aggregate surface roughness and high water absorption rate, but it does not affect the recycled concrete compactness since recycled aggregate absorbs water and liberate some air bubbles which helps their fluidity. Concrete mixtures were carried out in a mechanical mixer of $320 \mathrm{dm}^{3}$, observing this sequence of mixing: $100 \%$ of coarse aggregate; $50 \%$ of total water; $100 \%$ of cement; $25 \%$ of total water; $100 \%$ of fine aggregate; $25 \%$ of total water. The mixing time adopted was 8 minutes to guarantee the homogeneity of the concrete and to allow that recycled aggregate could absorb the additional water put into mixer. External vibration was used during casting. After removing the specimens from the molds they were cured at the humid chamber at $23 \pm 2^{\circ} \mathrm{C}$ and relative humidity of $100 \%$ until they have reached an age of 28 days.

\subsection{Test procedures}

Compressive tests were carried out in three cylindrical specimens of dimensions $100 \mathrm{~mm}$ in diameter and $200 \mathrm{~mm}$ in height, after 28 days of cure. The specimens were tested on a $1000 \mathrm{kN}$ SHIMAD$\mathrm{ZU}$ testing machine at a rate of axial displacement of $0.05 \mathrm{~mm} / \mathrm{min}$. The lateral and axial strain were measured using three electrical transducers (LVDT), as shown in Figure 6, and were continuously recorded, together with the corresponding loads, using a 32-bit data acquisition system taking four readings per second.

Compressive strength (fc), corresponding to peak stress, was obtained directly of stress-strain curves. The elastic modulus 
(Ec) and Poisson coefficient ( $v$ ) were calculated by eqn 1 and eqn 2, respectively, according ASTM C 469/02 - Standard test method for static modulus of elasticity and Poisson's ratio of concrete in compression.

$$
E_{C}=\frac{\sigma_{c 2}-\sigma_{c 1}}{\varepsilon_{a 2}-0.000050}
$$

$$
v=\frac{\varepsilon_{L 2}-\varepsilon_{L 1}}{\varepsilon_{a 2}-0.000050}
$$

were $\sigma_{\mathrm{c} 2}$ is the stress corresponding to the $40 \%$ of the peak stress; $\sigma_{c 1}$ is the stress corresponding to a strain of $0.00005 ; \varepsilon_{\mathrm{a} 2}$ is the strain at the stress level $\sigma_{\mathrm{c} 2} ; \varepsilon_{\mathrm{L} 2}$ is the lateral strain at the stress level $\sigma_{\mathrm{c} 2} ; \varepsilon_{\mathrm{L} 1}$ is the lateral strain at the stress level $\sigma_{\mathrm{c} 1}$.

To evaluable the effect of temperature, before compressive test, three samples of each mixture, with w/c ratio of 0.49 , were heated in the laboratory oven by 50,70 and $100^{\circ} \mathrm{C}$ during $24 \mathrm{~h}$.

Density tests were carried out in two cylindrical specimens of dimensions $100 \mathrm{~mm}$ in diameter and $200 \mathrm{~mm}$ in height according ASTM C642/06 - Standard test method for density, absorption, and voids in hardened concrete.
Statistical analysis was carried out using univariate (ANOVA) to determine the significance of the $\mathrm{w} / \mathrm{c}$ ratio and aggregate type on compressive strength and elastic modulus. To evaluate the influence of variation of temperature on compressive strength and elastic modulus, differences of the means were analyzed by using the Tukey test. Differences were considered significant at a 95\% confidence level.

\section{Analysis and discussion of results}

The experimental stress-curves obtained of compressive test are presented in Figure 7. Table 4 includes average results, obtained of three samples, for each mixture studied. The coefficient of variation, in \%, is shown in parenthesis.

\subsection{Influence of recycled aggregate}

The typical stress-strain curves shown in Figure 7 illustrates that the recycled aggregate has influence on the mechanical behavior of concrete. Nevertheless, the shape of the stress-strain curve for all the recycled aggregate concrete was similar to that of the natural aggregate concrete, the post cracking branch to EVA mixtures is more softening when compared with brittle behavior of reference concrete.

The influence of recycled aggregate on compressive strength and elastic modulus can be observed in Figure 8. Table 5 shows the ANOVA for these properties and indicates that $w / c$ ratio and type of aggregate are significantly important factors.

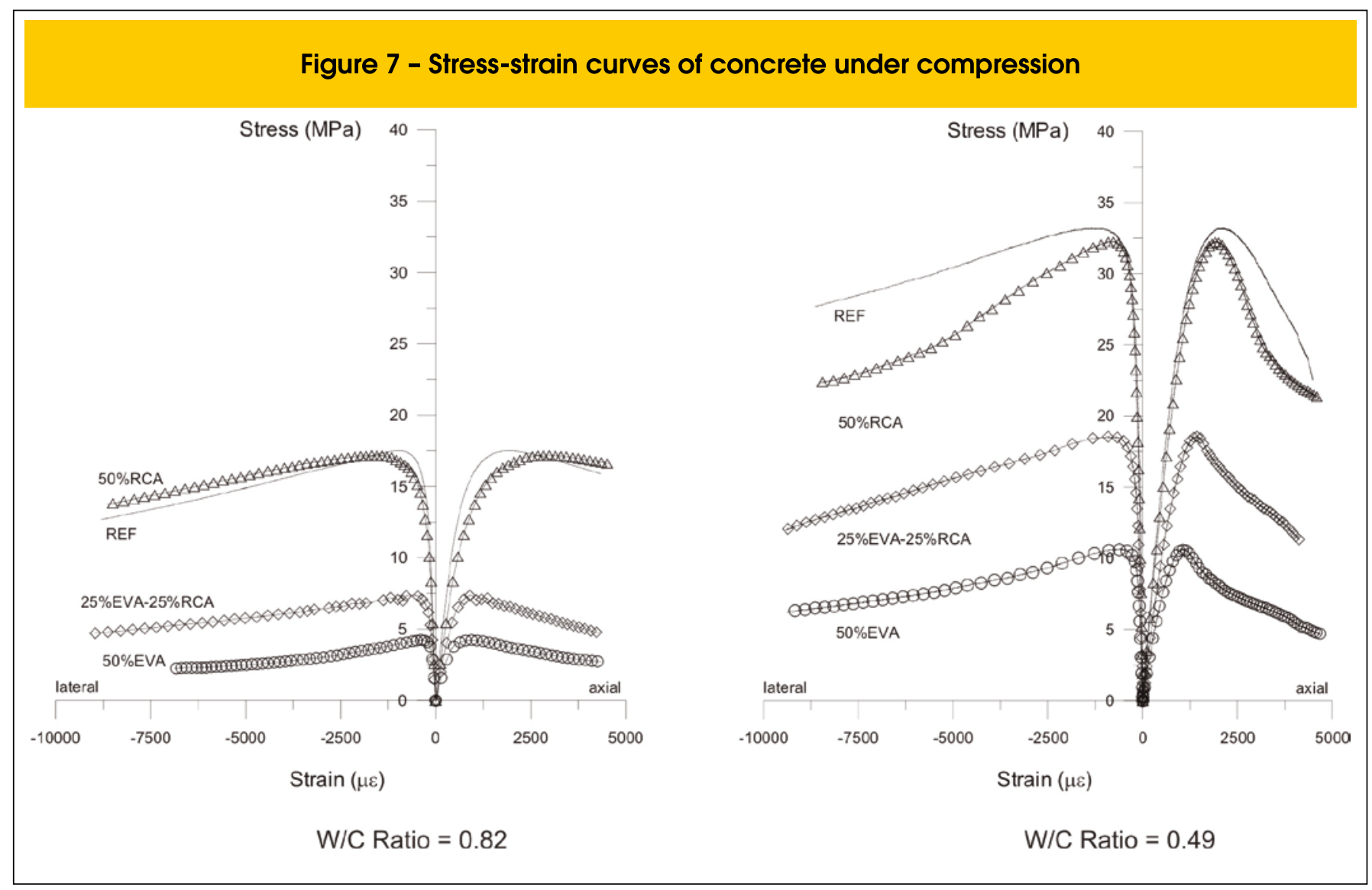


Independent of w/c ratio, it is verified that RCA didn't show important influence on compressive strength of concrete. In the other hand, $77 \%$ was the greatest reduction observed in this property when 50\%EVA was used, in comparison with reference concrete. The simultaneous use of the two recycled aggregates resulted in maximum reduction of $58 \%$. The EVA is a porous aggregate that has lower resistance to crushing resulting in low density concretes and with reduced compressive strength. The reduction of mechanical strength, in relation to conventional concrete, it is waited when lightweight aggregate is used [1].

The use of recycled aggregate reduced the elastic modulus of all mixtures. The $50 \% \mathrm{RCA}$ and $50 \% \mathrm{EVA}$ presents reduction of $17 \%$ and $53 \%$, respectively, relative to reference. The use simultaneous of two recycled aggregates resulted in reduction of $37 \%$ of elastic modulus. These reductions are the consequence of the application of the aggregate with a lower elastic modulus than that of the natural coarse aggregates. To RCA, this behavior is dependent of content of addition, composition and size of aggregate $[19,20,21]$. The effect of plastic aggregates on the elastic modulus was investigated by Al-Manaseer and Dalal (1997), apud [8], that verified that this property decrease with the increase in plastic content. The simultaneous use of plastic waste and recycled concrete aggregates was studied by Jo et al [22] that show reduction of compressive strength and elastic modulus with increment of content of recycled aggregate.

The Poisson coefficient for all mixtures remains about 0.2 and it was not affect by aggregate substitution.

The lightweight concrete shows lower compressive strength and elastic modulus than conventional concrete [2]. In Table 4 can be seen that the addition of recycled aggregate reduces the density for all mixtures. However, to produce lightweight concrete (density $<2,00 \mathrm{~kg} / \mathrm{dm}^{3}$ ) it was necessary the substitution of natural by EVA

Table 4 - Experimental results (in parenthesis, coefficient of variation in \%)

\begin{tabular}{|c|c|c|c|c|c|c|c|}
\hline \multirow{2}{*}{ Mixture } & \multirow{2}{*}{ W/C Ratio } & \multirow{2}{*}{$\begin{array}{c}\text { Temperature } \\
\left({ }^{\circ} \mathrm{C}\right)\end{array}$} & \multicolumn{3}{|c|}{ Compressive test } & \multirow{2}{*}{$\begin{array}{l}\text { Density } \\
\left(\mathrm{kg} / \mathrm{dm}^{3}\right)\end{array}$} & \multirow{2}{*}{$\begin{array}{l}\text { Slump } \\
\text { (mm) }\end{array}$} \\
\hline & & & fc (MPa) & Ec (GPa) & $v(\mathrm{~mm} / \mathrm{mm})$ & & \\
\hline \multirow{5}{*}{ REF } & \multirow[t]{2}{*}{0.82} & 23 & $17.88(2)$ & $26.80(4)$ & $0.19(6)$ & $2.27(0)$ & 65 \\
\hline & & 23 & $31.79(6)$ & $32.70(7)$ & $0.20(17)$ & $2.34(0)$ & 80 \\
\hline & \multirow{3}{*}{0.49} & 50 & $33.53(4)$ & $29.30(9)$ & 0.17 (18) & - & \\
\hline & & 70 & $36.27(1)$ & $30.30(2)$ & $0.20(6)$ & - & \\
\hline & & 100 & $35.90(4)$ & $28.20(1)$ & $0.18(8)$ & - & \\
\hline \multirow{5}{*}{$50 \%$ RCA } & \multirow[t]{2}{*}{0.82} & 23 & $17.43(2)$ & $20.9(7)$ & $0.17(1)$ & $2.15(0)$ & 55 \\
\hline & & 23 & $31.17(4)$ & $27.30(3)$ & 0.19 (7) & $2.21(1)$ & 80 \\
\hline & \multirow{3}{*}{0.49} & 50 & $34.20(1)$ & $25.70(1)$ & 0.19 (7) & - & \\
\hline & & 70 & $36.37(3)$ & $26.20(3)$ & 0.19 (2) & - & \\
\hline & & 100 & $36.80(5)$ & $23.20(6)$ & $0.18(8)$ & - & \\
\hline \multirow{5}{*}{$50 \%$ EVA } & \multirow[t]{2}{*}{0.82} & 23 & $4.12(3)$ & $10.70(8)$ & $0.24(11)$ & $1.65(2)$ & 15 \\
\hline & & 23 & $10.63(2)$ & $15.41(1)$ & $0.20(10)$ & $1.77(0)$ & 20 \\
\hline & \multirow{3}{*}{0.49} & 50 & $10.23(5)$ & 14.20 (19) & $0.21(13)$ & - & \\
\hline & & 70 & $10.70(4)$ & $12.70(4)$ & $0.16(4)$ & - & \\
\hline & & 100 & $10.13(5)$ & $11.21(9)$ & 0.17 (3) & - & \\
\hline \multirow{5}{*}{$\begin{array}{l}25 \% E V A \\
25 \% R C A\end{array}$} & 0.82 & 23 & $7.44(2)$ & $15.4(2)$ & $0.21(12)$ & $1.90(1)$ & 40 \\
\hline & \multirow{4}{*}{0.49} & 23 & $17.83(6)$ & $20.52(4)$ & $0.22(16)$ & $1.97(0)$ & 55 \\
\hline & & 50 & $19.133(5)$ & $19.7(5)$ & $0.19-10$ & - & \\
\hline & & 70 & $19.033(3)$ & $18.4(8)$ & $0.19-22$ & - & \\
\hline & & 100 & $19,400(1)$ & 17.7 (9) & $0.19-10$ & - & \\
\hline
\end{tabular}




\section{Figure 8 - Compressive Strength and elastic modulus of recycled concrete with relation reference concrete at $23^{\circ} \mathrm{C}$}
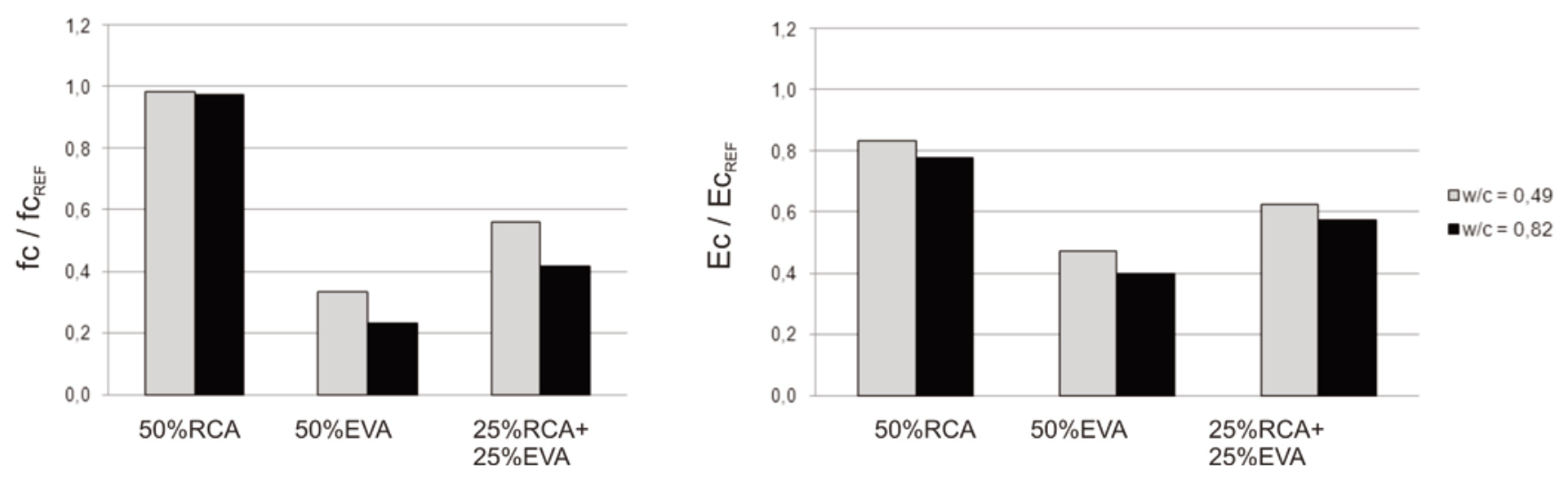

aggregate. The mixture with 50\%EVA reduces the density about $24 \%$. It was possible to reach compressive strength of about 18 $\mathrm{MPa}$, with lightweight concrete containing 25\%RCA and 25\%EVA in substitution of natural coarse aggregate. According RILEM [23] this concrete can be classified as structural concrete. Figure 9 presents that, using EVA waste and RCA, it is possible to obtain lightweight and conventional recycled concrete with structural and non structural properties.

\subsection{Influence of temperature}

The influence of the effect of temperature on the compressive strength and modulus of elasticity was evaluated by comparing the mean values of these properties for each pair of temperatures (50$70,50-100,70-100)$, as shown in Table 6 . It is shown that all pairs of means for resistance to compression are statistically equal $\left(q_{\text {calc }}\right.$

Table 5 - Analysis of variance (ANOVA) of mechanical property data

\begin{tabular}{|c|c|c|c|c|c|}
\hline Factor & Sums of squares & df & Mean squares & $\mathbf{F}$ & Fcritical \\
\hline & & & & & (95\%) \\
\hline \multicolumn{6}{|c|}{ Compressive strength } \\
\hline A: w/c ratio & 745.33 & 1 & 745.43 & 999.99 & 4.49 \\
\hline B: Type of aggregate & 1354.87 & 3 & 451.62 & 605.85 & 3.24 \\
\hline Interaction $A B$ & 54.93 & 3 & 18.31 & 24.56 & 3.24 \\
\hline Error & 11.93 & 16 & 0.74 & & \\
\hline Total SS & 2167.06 & 23 & & & \\
\hline \multicolumn{6}{|c|}{ Elastic Modulus } \\
\hline A: w/c ratio & 181.50 & 1 & 181.50 & 144.38 & 4.49 \\
\hline B: Type of aggregate & 950.33 & 3 & 316.76 & 251.99 & 3.24 \\
\hline Interaction $A B^{*}$ & 2.54 & 3 & 0.84 & 0.67 & 3.24 \\
\hline Error & 20.11 & 16 & 1.26 & & \\
\hline Total SS & 1154.48 & & & & \\
\hline
\end{tabular}




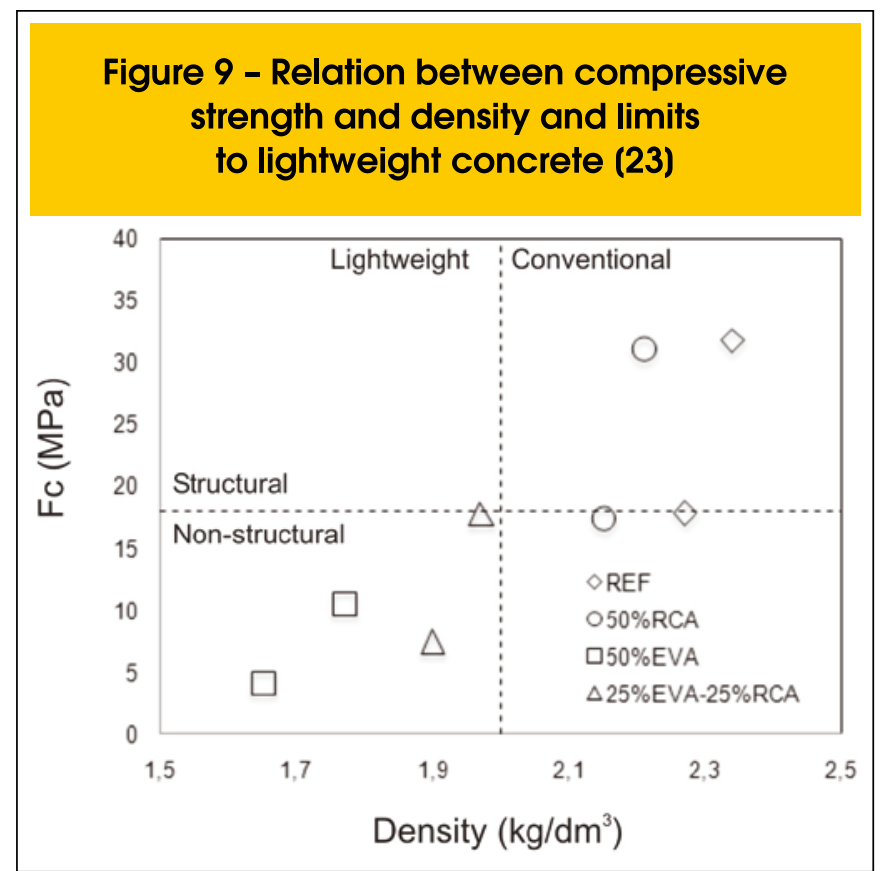

$<q_{\text {critical }}$ ). Regarding the modulus of elasticity, the mixture $50 \%$ RCA shows a significant difference between means for 50-100 and 70100 . Figure 10 presents the influence of temperature on compressive strength and elastic modulus of recycled concrete, relative to reference concrete with $w / c$ ratio of 0.49 . The relative compressive strength of recycled concrete with $50 \%$ RCA doesn't varies with increment of temperature. To concretes containing EVA, it is verified a slight reduction this property to temperatures of $70^{\circ} \mathrm{C}$ and $100^{\circ} \mathrm{C}$ This behavior of concrete with lightweight aggregate, to moderate temperature, it was verified by [24]. To relative modulus elastic, however, it is verified a reduction for all concretes, with increase of temperature. In conventional concrete, dehydration causes a decrease in its elastic modulus that can be attributed to the driving out of free water and fraction water of hydration [25]. To lightweight concrete, the porous structure of aggregate retain more water that conventional aggregate which increment this process. In recycled concrete, this fact also can be associated to change of structure of EVA aggregate, at $69^{\circ} \mathrm{C}$ [13] since, in Figure 1, it is not verified decomposition before $200^{\circ} \mathrm{C}$.

\section{Conclusion}

This study demonstrate that it's possible to use of solid wastes of shoes industry and construction industry as aggregate for production of lightweight concrete. Despite the reduction in compressive strength and elastic modulus, the combination of recycled aggregates to permit the production of a structural lightweight concrete.

From stress-strain curves for EVA concrete it was observed that the slope of descending branch decreased, when compared with conventional concrete, indicating an increment of toughness of material.

The effect of temperature it is more important on elastic modulus of concrete. To temperatures of 50,70 and $100^{\circ} \mathrm{C}$ it was verified a reduction this property of recycled concrete, as relation of conventional concrete. However, studies on the influence of elevate temperature (higher than $410^{\circ} \mathrm{C}$ ) must be performed to verify the release of any toxic gas into the recycled concrete in situation of fire.

Considering that no special treatment processes steps are required to production of recycled lightweight aggregate of EVA, their use as aggregate to production of concrete has economical and ecological advantages as compared with others lightweight aggregate.

\section{Acknowledgements}

The authors would like to thank the FAPESB (Fundação de Amparo a Pesquisa do Estado da Bahia) which sponsored the first author

Table 6 - Analysis of differences of the means of temperature (Tukey test)

\begin{tabular}{|c|c|c|c|c|c|}
\hline Pairs of temperature & & & $\mathrm{q}_{\text {calc }}$ & & $\mathbf{q}_{\text {critical }}$ \\
\hline & REF & $50 \%$ RCA & $50 \% E V A$ & $25 \% R C A-25 \% E V A$ & \\
\hline \multicolumn{6}{|c|}{ Compressive strength } \\
\hline $50^{\circ} \mathrm{C}-70^{\circ} \mathrm{C}$ & 4.20 & 2.87 & 1.60 & 0.29 & 4.34 \\
\hline $50^{\circ} \mathrm{C}-100^{\circ} \mathrm{C}$ & 3.64 & 3.44 & 0.34 & 0.76 & 4.34 \\
\hline $70^{\circ} \mathrm{C}-100^{\circ} \mathrm{C}$ & 0.56 & 0.57 & 1.94 & 1.05 & 4.34 \\
\hline \multicolumn{6}{|c|}{ Elastic modulus } \\
\hline $50^{\circ} \mathrm{C}-70^{\circ} \mathrm{C}$ & 1.10 & 0.92 & 1.58 & 1.68 & 4.34 \\
\hline $50^{\circ} \mathrm{C}-100^{\circ} \mathrm{C}$ & 1.29 & $4.70^{*}$ & 3.10 & 2.59 & 4.34 \\
\hline $70^{\circ} \mathrm{C}-100^{\circ} \mathrm{C}$ & 2.39 & $5.62^{*}$ & 1.51 & 0.91 & 4.34 \\
\hline
\end{tabular}


and the PROCAD/CAPES (Coordenação de Aperfeiçoamento de Pessoal de Nível Superior) for its support.

\section{References}

[ 1] MEHTA, PK.; MONTEIRO, PJM. Concreto: estrutura, propriedades e materiais. São Paulo:PINI, 1994. 573p.

[ 2] NEVILLE, A. M. Propriedades do concreto. PINI. São Paulo, 1997. 828p.

[ 3] BAI, Y; IBRAHIM, R; BASHEER, P. Properties of lightweight concrete manufactured with fly ash, furnace bottom ash, and lytag. In: International Workshop on Sustainable Development and Concrete Technology. 2004. p.77-88

[ 4] MORAVIA, WG; OLIVEIRA, CAS; GUMIERI, AG VASCONCELOS, WL. Caracterização microestrutural da argila expandida para aplicação como agregado em concreto estrutural leve. Cerâmica. V. 52. p.193-199, 2006. (In Portuguese)

[ 5] ANAGNOSTOPOULOS, IM; STIVANAKIS, VE. Utilization of lignite power generation residues for the production of lightweight aggregates. Journal of Hazardous Materials. V. 163. p.329-336, 2009.

[ 6] MONTEIRO, MA; RAUPP-PEREIRA, F; FERREIRA, VM; LABRINCHA, JA; DONDI, M. Lightweight aggregates made of industrial wastes or sub-products. In.International RILEM Conference on the Use of Recycled Materials in Buildings ans Structures. 2004. Barcelona.:p.107-114.

[ 7] SIDDIQUE, R.; KATHIB, J. KAUR, I. Use of recycled plastic in concrete: A review. Waste management. V.28. p.1835-1852, 2008.

[ 8] PANYAKAPO, P.; PANYAKAPO, M. Reuse of thermosetting plastic waste for lightweight concrete. Waste Management. V.28. p.1581-1588, 2008.

[ 9] PIMENTEL et al. Utilização de resíduos da indústria de calçados em blocos de vedação com novas geometrias - Bloco EVANG. In.: Inter American Conference on Non-Conventional Materials and
Technologies in Ecological and sustainable Construction. IAC-NOCMAT 2005 - Rio de Janeiro, 2005. p.386-395. (In Portuguese)

[10] INFORMES E NOTíCIAS. Polímeros, São Carlos, v. 13, n. 2, 2003. Disponível em: $<$ http://www.scielo.br/scielo.php?script=sci arttext\&pid=S0104-14282003000200004\&lng=en\&nrm=iso $>$. Acessado: 01 Dez 2006. (In Portuguese)

[11] STAIKOS, T.; RAHIMIFARD, S. Post-Consumer Waste Management Issues in the Footwear Industry. Proceedings of the Institution of Mechanical Engineers, Part B: Journal of Engineering Manufacture . V.221. N.2. p.363-368, 2007.

[12] UNIDO, 2000, Wastes Generated in the Leather Footwear Industry, 14th Session of the Leather and Leather Products Industry Panel, Czech Republic. [Online]: https://www.unido.org/userfiles/ timminsk/LeatherPanel14CTCwastes.pdf

[13] BRINGEL, RM; SOARES, SA; SOARES, JB. Propriedades químicas e reológicas de asfalto modificado por copolímero EVA. In.: $3^{\circ}$ Congresso Brasileiro de P\&D em Petróleo e Gás. Instituto Brasileiro de Petróleo e Gás - IBP - Salvador, 2005. (In Portuguese)

[14] TOPÇU, BI.; SENGEL, S. Properties of concretes produced with waste concrete aggregate. Cement and Concrete Research. V.34. N.8. p.1307-1312, 2004

[15] RAO, A.; JHA, K.; MISRA, S. Use of aggregates from recycled construction and demolition waste in concrete. Resources Conservation \& Recycling. V.50. p.71-81, 2007

[16] TABSH, S; ABDELFATAH, A. Influence of recycled concrete aggregates on properties of concrete. Construction and Building Materials. V.23. p.1163-1167, 2009.

[17] ZATTERA, AJ. et al. Caracterização de resíduos de Copolímeros de Etileno-acetato de vinila - EVA. Polímeros: Ciência e tecnologia. V.15. N.1. p.73-78, 2005. (In Portuguese)

\section{Figure 10 - Influence of temperature on variation of mechanical properties of recycled concrete}
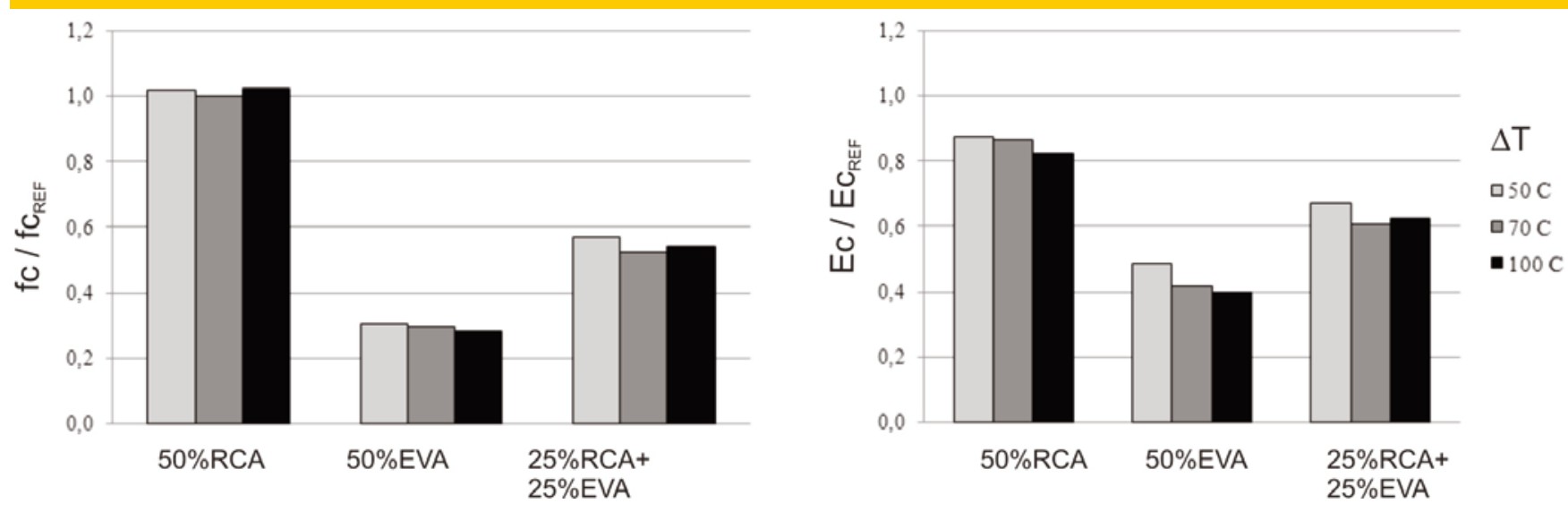
[18] LEITE, M. B. Avaliação de propriedades mecânicas de concretos produzidos com agregados reciclados de resíduos de construção e demolição.

Porto Alegre-RS, 2001. 270 p. Tese (Doutorado). Programa de Pós-Graduação em Engenharia Civil da Universidade Federal do Rio Grande do Sul. (In Portuguese)

[19] RAO, A; JHA, KN; MISRA, S. Use of aggregates from recycled construction and demolition waste in concrete. Resources Conservation \& Recycling. V.50. p. 71-81, 2007.

[20] XIAO, J.; LI, J.; ZHANG, C. Mechanical properties of recycled aggregate concrete under uniaxial loading. Cement and Concrete Research. V. 31. p.187-1194, 2005.

[21] CABRAL, AEB; SCHALCH,V.; DAL MOLIN, DCC.; RIBEIRO, JLD. Influence of the type of recycled aggregate from construction and demolition waste on the module of deformation of recycled aggregate concrete. Revista IBRACON de Estruturas e Materiais. V.1. N.2. p. 171-192, 2008.

[22] JO, B-W; PARK, S-K; PARK,J-C. Mechanical properties of polymer concrete made with recycled PET and recycled concrete aggregates. Construction and Building Materials. V. 22. p.2281-2291, 2008.

[23] RILEM. Classification fonctionelle des bétons légers. Matériaux et Constructions, Paris. V.11. N.64, 1978.

[24] TANYILDIZI, H.; COSKUN,A. The effect of high temperature on compressive strength and splitting tensile strength of structural lightweight concrete containing fly ash. Construction and Building Materials. V.22. p.2269-2275, 2008.

[25] SAKR, K; HAKIM, EE. Effect of high temperature or fire on heavy weight concrete properties. Cement and Concrete Research. V.35. N.3. p.590-6, 2005. 